\title{
Pengaruh Varietas dan Populasi Tanaman Terhadap Peningkatan Produtivitas Jagung Hibrida
}

\author{
Suwardi $^{1 *}$ dan Herawati ${ }^{2}$ \\ *e-mail: wardisereal@yahoo.co.id \\ 1,2 Balai Penelitian Tanaman Serealia \\ Jln. Dr. Ratulangi 274 Maros, Sulawesi Selatan, Indonesia
}

\begin{abstract}
Zea mays as food and feed material has continuously increases required along to population and stock farmer growth every year. To meet the high domestic demand while productive land is unable to compete with rice, it is necessary to increase production through the use of suitable varieties by increase the population per hectare from what has been implemented by farmers. This study aims to determine the effect of variety and plant population on increasing productivity of yield hybrid maize. This research was conducted at Indonesian Cereals Research Institute during August to November 2016. Split plot randomized block design with three replications was arranged for this experiment. The main plot were 8 (eight) Pioneer-21, Fasific 224, Bisi 2, Bima 3, Bima 4, Bima 5, Bima 19 and Bima 20. The subplots were two plant populations arrangement, which are common plant distance $70 \mathrm{~cm} \times 20 \mathrm{~cm}$ (population 71,428 per ha) and high population $70 \mathrm{~cm} \times 15 \mathrm{~cm}$ (population 95,238 per ha). The results showed that high population were increased production almost on all type variety except on Pionner 21 and Fasific 224. Increasing of 71,428 plant per ha population to 95,238 plant per ha, was resulted the highest production on Bisi 2 variety $(25,51 \%)$, Bima 4 variety $(25,38 \%)$ and Bima $19(25,94 \%)$.
\end{abstract}

Keywords: variety, population, productivity

\begin{abstract}
ABSTRAK
Jagung merupakan bahan pangan dan pakan yang terus meningkat kebutuhan nasional setiap tahunnya seiring bertambahnya jumlah penduduk dan peternak. Untuk memenuhi kebutuhan dalam negeri yang tinggi sementara lahan produktif kalah bersaing dengan tanaman padi, sehingga perlu dilakukan peningkatan produksi melalui penggunaan varietas yang sesuai dengan meningkatkan populasi tiap hektarnya dari yang sudah diterapkan oleh petani. Tujuan penelitian adalah untuk mengetahui pengaruh varietas dan populasi tanaman terhadap peningkatan produktivitas jagung hibrida. Penelitian ini dilaksanakan di Balai Penelitian Tanaman Serealia bulan Agustus - November 2016. Penelitian menggunakan rancangan acak kelompok dalam bentuk split plot dengan 3 ulangan. Petak utama adalah varietas sebanyak 8 (delapan) Pionner-21, Fasific 224, Bisi 2, Bima 3, Bima 4, Bima 5, Bima 19 dan Bima 20. Sebagai anak petak adalah populasi tanaman, yaitu normal $70 \mathrm{~cm} \times 20 \mathrm{~cm}$ (populasi 71.428) dan populasi tinggi 70 $\mathrm{cm} \times 15 \mathrm{~cm}$ (populasi 95.238). Hasil penelitian menujukkan bahwa peningkatan populasi terjadi kenaikkan produksi yang besarnya tergantung dari jenis varietas kecuali Pionner 21 dan Fasific 224 terjadi penurunan produksi. Populasi 71.428 tan/ha ditingkatkan menjadi 95.238 tan/ha peningkatan produksi tertinggi yaitu varietas Bisi 2 $(25,51 \%)$, varietas Bima 4 (25,38\%) dan Bima 19 (25,94\%).
\end{abstract}

Kata kunci: varietas, populasi, produktivitas 


\section{PENDAHULUAN}

Produktivitas jagung nasional yang masih rendah yang disebabkan oleh penggunaan benih non unggul, kendala musim dan teknologi budidaya yang kurang tepat. Produktivitas jagung yang rendah disebabkan oleh teknik budidaya yang tidak tepat, penggunaan varietas lokal, serangan hama, daya tumbuh kurang $90 \%$ dan dosis pupuk NPK yang tidak optimal (Kartika, 2018).

Untuk peningkatan produktivitas jangung nasional ditempuh melalui penggunaan benih yang unggul, bermutu, jarak tanam (populasi) yang sesuai dengan tipe tanaman dan pemeliharaan selama pertumbuhan tanaman. Penggunaan benih tidak unggul dan bermutu, berpengaruh terhadap produktivitas dan daya tumbuh. Daya tumbuh yang kurang dari $90 \%$ berpengaruh terhadap produktivitas tiap satuan hektar. Jarak tanam berpengaruh jumlah tanaman tiap hektarnya sehingga berhubungan erat dengan produktivitasnya. Penggunaan jarak tanam yang tepat dengan bertambahnya jumlah populasi tanaman memberikan produktivitas yang tinggi. Pengaturan jarak tanam atau kepadatan tanaman tiap satuan luas agar tanaman mendapatkan bagian yang sama dalam memperoleh unsur hara, sinar matahari, ruang tumbuh dan memudahkan pemeliharaan (Kartika, 2018).

Untuk untuk meningkatkan produktivitas tanaman jagung malalui peningkatan populasi tiap satuan luas dengan mempertimbang tipe morfologi tanaman. Morfologi tanaman terutama yang memiliki tipe daun tegak dan lebar berpeluang besar untuk ditingkatkan populasi tiap satuan luas. Tipe daun yang tegak dan lebar memiliki kelebihan tingkat penerimaan cahaya matahari lebih besar dibanding tipe daun yang datar dan sempit. Semakin besar/lama penerimaan cahaya matahari, maka proses fotosintesis semakin lama/optimal dan hasil fotosintesis ditraskolasikan dalam pertumbuhan tanaman dan biji. Kemampuan produktivitas tanaman tergantung penyerap dan mengkonversi energi dari cahaya matahari melalui proses fotosintesis yang ditraskolasikan untuk pertumbuhan dan biji (biomasa tanaman) (Campillo et. al., 2012).

Teknologi budidaya jagung untuk meningkatkan produktivitas adalah pengaturan jarak tanam dengan mempertibangkan sifat morfologi tanaman terutama tipe daun yang tegak dan lebar sehingga populasi tiap hektar dapat ditingkatkan dan tanaman mengoptimalkan penerimaan cahaya matahari, air, hara dan ruang tumbuh optimum yang rendah, sehingga produktivitas optimal. Dalam peningkatkan populasi tanaman perlu dipertimbangkan intensitas cahaya matahari yang diterima tiap daun sehingga hasil tanaman meningkat dan proses fotosintesis dapat maksimal yang berdampak positif terhadap pertumbuhan dan hasil (Alislami dan Suryanto, 2018); (Nurbaiti dkk, 2017). Pada populasi yang tinggi menurunkan intersepsi cahaya, sehingga daun bagian bawah tidak memperoleh cahaya matahari yang mengakibatkan ratio sumber-sink dan ukuran bobot biji menurun (Borra's et. al., 2003). Dengan pengaturan jarak tanam yang sesuai morfologi tanaman sehingga daun bagian bawah memperoleh cahaya matahari untuk fotosintesis pada populasi tinggi lebih optimal, sehingga peluang dapat meningkatkan produktivitas tiap satuan luas.

Tujuan penelitian adalah untuk mengetahui pengaruh varietas dan populasi tanaman terhadap peningkatan produktivitas jagung hibrida.

\section{BAHAN DAN METODE}


Penelitian ini dilaksanakan di KP. Maros, Balai Penelitian tanaman Serealia bulan Agustus-November 2016. Penelitian menggunakan rancangan acak kelompok dalam bentuk split plot dengan 3 ulangan. Petak utama adalah varietas sebanyak 8 (delapan) varietas (Pionner-21, Fasific 224, Bisi 2, Bima 3, Bima 4, Bima 5, Bima 19 dan Bima 20). Sebagai anak petak adalah populasi tanaman, yaitu normal $70 \mathrm{~cm}$ x $20 \mathrm{~cm}$ (populasi 71.428) dan populasi tinggi 70 $\mathrm{cm} \times 15 \mathrm{~cm}$ (populasi 95.238). Penanaman 2 biji per lubang ditanam dan pada 10 hst dilakukan penjarangan hingga ditumbuhkan 1 tanaman/rumpun. Ukuran plot yang digunakan setiap perlakuan adalah $2.8 \mathrm{~m}$ x $6 \mathrm{~m}$

Dosis pupuk yang digunakan adalah $200 \mathrm{~kg} \mathrm{~N} / \mathrm{ha}+60 \mathrm{~kg} \mathrm{P}_{2} \mathrm{O}_{5}+60 \mathrm{~kg}$ $\mathrm{K}_{2} \mathrm{O}$ per ha. Pemupukan dilakukan 2 kali, yaitu separuh takaran $\mathrm{N}$ dan seluruh takaran $\mathrm{P}$ dan $\mathrm{K}$ diberikan pada umur $<10$ hst, sisa takaran $\mathrm{N}$ diberikan umur 40 hst. Untuk pemeliharaan, terutama gulma dilakukan dengan penyemprotan herbisida Calaris dengan takaran 2,0 1/ha yang diberikan sebelum pemupukan pertama. Penyiangan dan pembumbunan sebelum pemupukan ke dua dilakukan secara manual atau dengan hand traktor.

Data yang diamati : klorofil daun (unit), komponen agronomis, antara lain; tinggi tanaman (30 hari setelah tanam (hst) dan 70 hst), tinggi letak tongkol (70 hst), panjang daun dan lebar daun, jumlah daun, komponen hasil (panjang dan diameter tongkol, jumlah baris per tongkol, biji dalam baris, bobot 100 biji) dan hasil biji (t/ha). Pengamatan nilai klorofil daun menggunakan alat SPAD Model 401 pada umur 30 hari setelah tanam (hst) dan 70 hst. Tinggi tanaman diukur dari permukaan tanah sampai ruas daun terbuka sempurna teratas, sedang tinggi letak tongkol diukur dari permukaan tanah sampai ruas kedudukan tongkol setiap tanaman. Panjang daun diukur dari daun pangkal sampai ujung daun pada satu daun diatas tongkol, sedang lebar daun diukur tengah daun pada satu daun di atas tongkol. Jumlah daun dihitung dari daun terbawah sampai daun teratas yang telah terbuka sempurna. Panjang tongkol diukur pada pangkal sampai dengan ujung tongkol, sedang diameter tongkol diukur dibagian tengah tongkol dengan menggunakan alat sigma. Jumlah baris dihitung tiap tongkol dengan keliling tiap tongkol dan jumlah biji dalam baris dihitung biji tiap baris dalam 1 tongkol. Bobot biji dengan mengitung 100 biji dan ditimbang menggunakan timbangan analitik. Untuk mengetahui produktivitas tiap hektar dengan memanen yang telah ditentukan luas panen, rendemen dan kadar air panen. Hasil (t/ha) tiap varietas menurut Firdaus, dkk. (2002) menggunakan rumus:

Hasil $(t / h a)=\frac{10000}{L . P} \times \frac{100-K A}{100-15} \times B \times 0.80$

Keterangan :

K. $A=$ Kadar air biji saat panen

L. $\mathrm{P}=$ Luas panen $\left(\mathrm{m}^{2}\right)$

$15=$ Kadar air biji 15\%

$\mathrm{B}=$ Bobot tongkol kupasan panen $(\mathrm{kg})$

$0.80=$ Rata-rata "shelling percentage (rendemen)"

Data hasil pengamatan diolah dan dianalisis dengan sidik ragam taraf kesalahan $5 \%$ apabila pengaruh perlakuan nyata Duncan (Duncan Multiple Range Test) pada taraf $\alpha$ 5\%.

\section{HASIL DAN PEMBAHASAN}

\section{Tinggi Tanaman 30 hst}

Berdasarkan hasil analisis dapat diketahui bahwa terjadi interaksi antar vaietas dengan populasi tanaman $30 \mathrm{hst}$. Rata-rata tinggi tanaman $30 \mathrm{hst}$ berpengaruh nyata antar varietas yaitu Pionner 21 dan Fasifik 224 dengan varietas lain yang diuji (populasi 71.428 $\tan /$ ha dan populasi 95.238 tan./ha) 
(Tabel 1). Tanaman pada 30 hst varietas Pionner 21, Bisi 2, Bima 3, dan Bima 19 dari populasi $71.428 \mathrm{tan} /$ ha ke populasi $95.238 \mathrm{tan} /$ ha terjadi peningkatan tinggi tanaman. Hal ini menunjukkan bahwa varietas tersebut dengan peningkatan populasi terjadi kompetisi cahaya matahari, sehingga tanaman cenderung tinggi untuk mendapatkan cahaya matahari. Persaingan untuk mendapatkan cahaya matahari dan air menyebabkan terjadinya berbagai respons tanaman yang bersifat aditif, sinergis atau antagonis (Zhang et. al., 2011). Untuk pertumbuhan tanaman diperlukan penerimaan cahaya matahari yang optimal dalam proeses fotosintesis yang hasilnya ditraskolasikan ke batang, daun dan biji. Berkurangnya cahaya matahari mengakibatkan proses fotosintesis berkurang, sehingga alokasi fotosintesat untuk pembentukan organ vegetatif maupun reproduktif menurun (Sundari dan Mutmaidah, 2018). Produktivitas suatu tanaman tergantung dari kemampuan tanaman dalam menerima dan mengkonversi energi cahaya matahari melalui proses fotosintesis yang akan ditraskolasikan untuk pertumbuhan dan biji (biomasa tanaman) (Campillo et. al., 2012).

Varietas Bima 4 pada 30 hst dari populasi 71.428 tan/ha ditingkatkan menjadi 95.238 tan./ha terjadi penurunan tinggi tanaman. Hal ini menujukkan bahwa varietas tersebut dengan populasi yang lebih tinggi terjadi kompetisi hara, cahaya matahari dan ruang tumbuh, sehingga pertumbuhan tanaman terhambat. Terjadi persaingan untuk mendapatkan cahaya, unsur hara dan air mengaibatkan berbagai respons tanaman yang bersifat aditif, sinergis atau antagonis (Zhang et. al., 2011).

Tingkat populasi $71.428 \mathrm{tan} / \mathrm{ha}$ dan $95.238 \tan /$ ha varietas Fasific 224 tidak terjadi pengaruh pada tinggi tanaman pada 30 hst. Hal ini menunjukkan bahwa varietas Fasific 224 dengan peningkatan populasi tidak terjadi kompetisi air, unsur hara, cahaya matahari, dan ruang tumbuh yang siknifikan, sehinga tinggi tanaman tidak berpengaruh nyata dengan tingkat populasi yang berbeda. Varietas Fasific 224 dengan peningkatan populasi dapat meminimal kompetisi intrapopulasi kanopi dan akar tanaman dan memanfaatkan lingkungan secara optimal. Tujuan pengaturan kerapatan tanaman adalah untuk dapat meminimalkan tingkat kompetisi intrapopulasi agar kanopi daun dan akar tanaman dapat memanfaatkan lingkungan (cahaya, air dan unsur hara) secara maksimal (Gardner et. al., 1996).

Tabel 1. Rata-rata tinggi tanaman $30 \mathrm{hst}$ jarak tanam $70 \quad$ x $20 \quad \mathrm{~cm}$ (populasi 71.428 tanaman per hektar (tan./ha) dan $70 \times 15 \mathrm{~cm}$ (populasi 95.238 (tan./ha).

\begin{tabular}{|l|l|l|}
\hline \multirow{2}{*}{ Varietas } & \multicolumn{2}{|c|}{ Tinggi tanaman $(\mathrm{cm}) 30$ hst } \\
\cline { 2 - 3 } & \multicolumn{1}{|c|}{ Populasi tanaman per hektar } \\
\cline { 2 - 3 } & 71.428 & \multicolumn{1}{c|}{95.238} \\
\hline Pionner 21 & $31.11 \mathrm{a}$ & $32.44 \mathrm{a}$ \\
\hline Fasific 224 & $30.77 \mathrm{a}$ & $30.77 \mathrm{a}$ \\
\hline Bisi 2 & $25.61 \mathrm{bc}$ & $26.61 \mathrm{~b}$ \\
\hline Bima 3 & $25.83 \mathrm{bc}$ & $26.55 \mathrm{~b}$ \\
\hline Bima 4 & $27.00 \mathrm{~b}$ & $25.89 \mathrm{~b}$ \\
\hline Bima 5 & $25.33 \mathrm{bc}$ & $25.05 \mathrm{~b}$ \\
\hline Bima 19 & $24.72 \mathrm{c}$ & $25.55 \mathrm{~b}$ \\
\hline Bima 20 & $26.00 \mathrm{bc}$ & $25.83 \mathrm{~b}$ \\
\hline Rata-rata & 27.04 & 27.34 \\
\hline
\end{tabular}

Angka yang diikuti huruf yang sama tidak berbeda nyata pada taraf 5\% menurut uji Duncan

\section{Tinggi Tanaman dan Letak Tongkol}

Tinggi tanaman 70 hst dari berbagai varietas pada populasi 71.428 tan./ha hasil analisis menunjukkan varietas Fasifik 224 Bisi 2 berbeda nyata dengan Bima 3, Bima 4, Bima 5, Bima 19 
dan Bima 20 (Tabel 2). Populasi mempengaruhi pertumbuhan tanaman (tinggi tanaman) sesuai kemampuan tanaman dalam mengoptimalkan cahaya matahari, unsur hara, air dan lingkungan tumbuh pada varietas tersebut. Varietas yang mampu mengoptimalkan cahaya, air, unsur hara dan ruang tumbuh memberikan pertumbuhan yang optimal. Tinggi tanaman populasi $95.238 \mathrm{tan} / \mathrm{ha}$ varietas Bisi 2 berbeda nyata dengan varietas Pionner 21, Fasifi 224, Bima 3, Bima 4, Bima 5, Bima 19 dan Bima 20. Masing-masing varietas pada populasi 95.238 tan./ha memiliki kemampuan yang berbeda terhadap tinggi tanaman, hal ini dipengaruhi oleh faktor genetik dan lingkungan tumbuh. Pertumbuhan dan produktivitas tanaman jagung sangat nyata dipengaruhi oleh jarak tanam dan jenis varietas (Yulisma, 2011).

Varietas Pionner 21, Bima 3, dan Bima 20 dari populasi 71.428 tan/ha ditingkatkan menjadi 95.238 tan/ha terjadi penurunan tinggi tanaman. Dengan peningkatan populasi dari tiga varietas tersebut terjadi kompetisi cahaya, air, unsur hara dan ruang tumbuh antar tanaman sehingga tinggi tanaman menurun. Semakin tinggi populasi tanaman tingkat kompetisi cahaya matahari meningkat yang mengakibatkan proses fotosinesis menurun, sehingga jumlah pasokan fotosintat menurun sehingga mengganggu pertumbuhan tanaman. Jarak tanam yang semakin rapat mengakibatkan cahaya matahari yang diterima oleh daun tanamam berkurang, mengakibatkan proses fotosintesis terhambat dan pasokan fosintat berkurang sehingga produksi tanaman menurun (Aisah dan Herlina, 2018).

Varietas Bisi 2, Bima 4, Bima 5, dan Bima 19 dengan peningkatan populasi nilai tinggi tanaman cenderung naik. Hal ini menujukkan bahwa empat varietas tersebut dengan meningkatnya populasi terjadi kompetisi untuk mendapatkan cahaya matahari yang optimal, sehingga tanaman cenderung naik seiring peningkatan populasi tanaman. Terjadinya peningkatan tinggi tanaman karena adanya pemanjangan ruas batang untuk menghindari kekurangan cahaya matahari dalam mendapatkan cahaya matahari lebih banyak pada kondisi tanaman ternaungi (Li, et. al., 2006); (Franklin, 2008); (Sundari dkk, 2018). Tinggi tanaman dan jumlah daun dipengaruhi tingkat komptisi air, cahaya matahari dan ruang tumbuh antar tanaman (Aisah dan Herlina, 2018). Varietas Fasifik 224 dengan peningkatan populasi tidak terjadi kenaikkan nilai tinggi tanaman. Hal ini menunjukkan bahwa varietas Fasifik 224 mampu memanfaatkan unsur hara, cahaya matahari, air dan ruang tumbuh, sehingga tidak berpengaruh tinggi tanaman. Pada umumnya produksi per satuan luas yang tinggi pada populasi tertentu dapat memanfaatkan penggunaan cahaya matahari secara maksimal (Kartika, 2018).

Hasil analisis menujukkan bahwa tinggi letak tongkol varietas Bisi 2 berbeda nyata dengan varietas lain pada populasi $71.428 \mathrm{tan} / \mathrm{ha}$, sedang populasi 95.238 tan./ha berbeda nyata dengan varietas Bima 3, Bima 4, Bima 5 dan Bima 20 (Tabel 2). Hal ini menunjukkan bahwa varietas Bisi 2 memiliki nilai tinggi letak tongkol lebih besar dibanding varietas lain pada dua populasi tersebut yang dipengaruhi oleh faktor genetik dan lingkungan tumbuh. Dengan peningkatan populasi varietas Bisi 2 tidak terjadi kompetisi antar tanaman dalam memperoleh cahaya matahari, unsur hara dan ruang tumbuh. Untuk memperoleh cahaya matahari yang optimal dalam proses fotosintesisnya tanaman cenderung terjadi pemanjangan ruas batang sehingga tinggi tanaman dan tinggi letak tongkol meningkat pada varietas Bisi 2. Tanaman yang adaptif terhadap radiasi rendah akan terjadi peningkatan rasio luas daun, rasio 
diameter batang, panjang batang dan penurunan ketebalan daun (Haque et. al., 2009). Tinggi tanaman dan tinggi letak tongkol pada berbagai varietas dan populasi yang sama berkorelasi, yaitu semakin tinggi suatu tanaman maka tinggi letak tongkol semakin tinggi pula. Tinggi tanaman dan tinggi letak tongkol berkorelasi yaitu semakin tinggi tanaman maka tinggi letak tongkol semakin tinggi tergantung dari sifat genetiknya (Suwardi dan Fauziah, 2016).

Tabel 2. Rata-rata tinggi tanaman dan letak tongkol 70 hst jarak tanam 70 x $20 \mathrm{~cm}$ (populasi $71.428 \tan . /$ ha) dan $70 \times 15 \mathrm{~cm}$ (populasi 95.238 tan./ha).

\begin{tabular}{|l|l|l|l|l|}
\hline \multirow{2}{*}{ Varietas } & \multicolumn{3}{|c|}{ Tinggi tanaman $(\mathrm{cm})$} & \multicolumn{1}{c|}{ Tinggi letak tongkol (cm) } \\
\cline { 2 - 5 } & \multicolumn{4}{|c|}{ Populasi tanaman per hektar } \\
\cline { 2 - 5 } & \multicolumn{1}{|c|}{71.428} & \multicolumn{1}{|c|}{91.428} & \multicolumn{1}{c|}{95.238} \\
\hline Pionner 21 & $170.55 \mathrm{ab}$ & $163.61 \mathrm{bcd}$ & $66.50 \mathrm{~b}$ & $71.94 \mathrm{ab}$ \\
\hline Fasific 224 & $175.44 \mathrm{a}$ & $175.61 \mathrm{ab}$ & $61.39 \mathrm{~b}$ & $72.50 \mathrm{ab}$ \\
\hline Bisi 2 & $181.88 \mathrm{a}$ & $187.22 \mathrm{a}$ & $85.27 \mathrm{a}$ & $86.78 \mathrm{a}$ \\
\hline Bima 3 & $159.72 \mathrm{bc}$ & $158.33 \mathrm{cde}$ & $58.89 \mathrm{~b}$ & 65.16 \\
\hline Bima 4 & $156.66 \mathrm{c}$ & $158.83 \mathrm{cde}$ & $61.72 \mathrm{~b}$ & $65.28 \mathrm{~b}$ \\
\hline Bima 5 & $148.27 \mathrm{c}$ & $150.94 \mathrm{de}$ & $64.44 \mathrm{~b}$ & $63.05 \mathrm{~b}$ \\
\hline Bima 19 & $159.27 \mathrm{bc}$ & $169.28 \mathrm{bc}$ & $65.83 \mathrm{~b}$ & $71.55 \mathrm{ab}$ \\
\hline Bima 20 & $150.33 \mathrm{c}$ & $146.22 \mathrm{e}$ & $62.77 \mathrm{~b}$ & $59.16 \mathrm{~b}$ \\
\hline Rata-rata & 162.77 & 163.75 & 65.85 & 69.43 \\
\hline
\end{tabular}

Angka yang diikuti huruf yang sama tidak berbeda nyata pada taraf 5\% menurut uji Duncan

\section{Panjang dan Lebar Daun}

Hasil analisis menunjukkan bahwa panjang daun varietas Bima 3 dan Bima 5 berbeda nyata dengan varietas Pionner 21, dan Fasific 224 pada populasi 71.428 tan/ha, sedang pada populasi 95.238 tan./ha berbeda nyata dengan Pionner. Masing-masing varietas pada populasi 71.428 tan/ha panjang daun nilai sangat variatif, sedang populasi 95.238 tan./ha nilai hampir sama, hal ini menunjukkan bahwa panjang daun dengan populasi rendah masing-masing varietas masih memberikan nilai yang variatif sedang pada populasi tinggi nilainya hampir sama akibat terjadinya kompetisi unsur hara, air, cahaya matahari dan ruang tumbuh. Jarak tanam/populasi sangat berpengaruh terhadap pertumbuhan dan produktivitas tanaman (Yulisma, 2011).

Lebar daun varietas Bima 3 berbeda nyata dengan seluruh varietas pada populasi 71.428 tan./ha, sedang populasi 95.238 tan./ha berbeda nyata dengan varietas Pionner 21, Fasific 224, dan Bisi 2. Seluruh varietas terjadi penurunan nilai lebar daun seiring meningkatnya populasi tan./ha, hal ini menunjukkan bahwa peningkatan populasi terjadi kompetisi antar tanaman sehingga pertumbuhan daun terganngu. Peningkatan populasi tanaman akan terjadi penurunan produktivitas karena adanya kompetisi hara, cahaya matahari dan kelembaban lingkungan tumbuh (Erawati dan Hippi, 2015). 
Tabel 3. Rata-rata panjang dan lebar 70 hst jarak tanam $70 \times 20 \mathrm{~cm}$ (populasi 71.428 tan./ha) dan $70 \times 15 \mathrm{~cm}$ (populasi $95.238 \mathrm{tan} . / \mathrm{ha})$

\begin{tabular}{|l|l|l|l|l|}
\hline \multirow{2}{*}{ Varietas } & \multicolumn{3}{|c|}{ Panjang daun $(\mathrm{cm})$} & \multicolumn{1}{c|}{ Lebar daun $(\mathrm{cm})$} \\
\cline { 2 - 5 } & \multicolumn{4}{|c|}{ Populasi tanaman per hektar } \\
\cline { 2 - 5 } & \multicolumn{1}{|c|}{71.428} & \multicolumn{1}{|c|}{95.238} & \multicolumn{1}{c|}{71.428} & \multicolumn{1}{c|}{95.238} \\
\hline Pionner 21 & $72.89 \mathrm{c}$ & $70.94 \mathrm{~b}$ & $8.00 \mathrm{c}$ & $7.75 \mathrm{c}$ \\
\hline Fasific 224 & $76.23 \mathrm{bc}$ & $76.11 \mathrm{ab}$ & $8.76 \mathrm{~b}$ & $8.22 \mathrm{bc}$ \\
\hline Bisi 2 & $81.77 \mathrm{ab}$ & $79.94 \mathrm{a}$ & $8.40 \mathrm{bc}$ & $7.96 \mathrm{c}$ \\
\hline Bima 3 & $83.22 \mathrm{a}$ & $79.00 \mathrm{a}$ & $9.69 \mathrm{a}$ & $9.31 \mathrm{a}$ \\
\hline Bima 4 & $79.61 \mathrm{ab}$ & $79.11 \mathrm{a}$ & $8.74 \mathrm{~b}$ & $8.44 \mathrm{abc}$ \\
\hline Bima 5 & $83.50 \mathrm{a}$ & $82.94 \mathrm{a}$ & $8.87 \mathrm{~b}$ & $8.76 \mathrm{abc}$ \\
\hline Bima 19 & $78.89 \mathrm{abc}$ & $82.94 \mathrm{a}$ & $8.65 \mathrm{~b}$ & $9.23 \mathrm{ab}$ \\
\hline Bima 20 & $79.33 \mathrm{ab}$ & $76.00 \mathrm{ab}$ & $8.47 \mathrm{bc}$ & $8.29 \mathrm{abc}$ \\
\hline Rata-rata & 79.43 & 78.37 & 8.70 & 8.49 \\
\hline
\end{tabular}

Angka yang diikuti huruf yang sama tidak berbeda nyata pada taraf 5\% menurut uji Duncan

\section{Jumlah Daun}

Jumlah daun pada populasi 71.428 tan./ha 70 hst menunjukkan bahwa varietas Bisi 2 dan Bima 5 berbeda nyata dengan Bima 4, namun tidak berbeda nyata dengan varietas Pionner 21, Bima 3, Bima 19 dan Bima 20 (Tabel 4). Populasi tanaman dari 71.428 tan./ha ke 95.238 tan./ha secara umum terjadi penurunan jumlah daun. Peningkatan populasi terjadi kompetisi antar tanaman yang mengakibatkan penurunan nilai jumlah daun. Jumlah daun merupakan indikator pertumbuhan dan parameter untuk menggambarkan kemampuan tanaman dalam proses fotosensis dan hasilnya ditranskolasikan ke bagian tanaman. Tinggi tanaman dan jumlah daun sangat dipengaruhi oleh tingkat kompetisi (air cahaya matahari dan ruang tumbuh ) antar tanaman, yaitu semakin sempit jarak tanam semakin tinggi tingkat kompetisi antar tanaman (Aisah dan Herlina, 2018). Namun disisi lain jumlah daun yang banyak juga menyebabkan terjadinya parasit (ternaungi oleh daun bagian atas) karena hasil fotosintesis tidak ditranskolasi ke biji melainkan digunakan sumber makanan oleh daun bagian bawah yang tidak mendapatkan sinar matahari. Posisi daun yang kurang memperoleh cahaya matahari dapat menjadi bersifat parasit jika sinar matahari yang diterima daun tidak mampu menghasilkan karbohidrat lebih banyak dari yang dibutuhkan untuk pemeliharaan daun tersebut (Ramli, 2019).

Tabel 4. Rata-rata jumlah daun 70 hst jarak tanam $70 \times 20 \mathrm{~cm}$ (populasi 71.428 tan./ha) dan $70 \times 15 \mathrm{~cm}$ (populasi 95.238 tan./ha).

\begin{tabular}{|c|c|c|}
\hline \multirow{3}{*}{ Varietas } & \multicolumn{2}{|c|}{ Jumlah daun (helai) } \\
\hline & \multicolumn{2}{|c|}{$\begin{array}{c}\text { Populasi tanaman per } \\
\text { hektar }\end{array}$} \\
\hline & 71.428 & 95.238 \\
\hline Pionner 21 & $13.22 \mathrm{ab}$ & $12.61 \mathrm{bc}$ \\
\hline Fasific 224 & $11.77 b c$ & $11.27 \mathrm{c}$ \\
\hline Bisi 2 & $13.44 \mathrm{a}$ & $13.66 \mathrm{ab}$ \\
\hline Bima 3 & $13.22 \mathrm{ab}$ & $13.28 \mathrm{ab}$ \\
\hline Bima 4 & $11.67 \mathrm{c}$ & $13.83 \mathrm{ab}$ \\
\hline Bima 5 & $13.72 \mathrm{a}$ & $14.50 \mathrm{a}$ \\
\hline Bima 19 & $12.33 \mathrm{abc}$ & $13.39 \mathrm{ab}$ \\
\hline Bima 20 & $12.27 \mathrm{abc}$ & $13.55 \mathrm{ab}$ \\
\hline Rata-rata & 12.70 & 13.26 \\
\hline
\end{tabular}

Angka yang diikuti huruf yang sama tidak berbeda nyata pada taraf 5\% menurut uji Duncan. 


\section{Klorofil Daun 30 dan 70 hst}

Hasil analisis menunjukkan nilai klorofil daun 30 hst dengan populasi $71.428 \mathrm{tan} / \mathrm{ha}$ varietas Pionner 21 berbeda nyata Bisi 2, namun tidak berbeda nyata Fasific 224, Bima 3, dan Bima 5. Sedang populasi 95.238 tan./ha varietas Bima 3 dan Bima 5 berbeda nyata dengan Bisi 2 , namun tidak berbeda nyata varietas Pionner 21, Fasific 224, Bima 4 dan Bima 19 (Tabel 5). Hal ini menunjukkan bahwa tingkat kemampuan tanaman terhadap penyerapan unsur hara dalam tanah berbeda tergantung jenis varietas dan tingkat populasi tanaman tiap hektarnya. Pada 30 hst masingmasing varietas terjadi penurunan nilai klorofil dengan adanya peningkatan populasi. Semakin meningkat populasi tanaman maka semakin tinggi kompetisi daun untuk memperoleh cahaya matahari akibat meningkatnya daun yang ternaungi. Daun yang ternaungi akan menjadi parasit bagi tanaman karena daun tersebut tidak terjadi proses fotosintesis namun membutuhkan hasil fotosintesis, sehingga berpengaruh terhadap nilai klorofil daun. Jumlah daun, sebaran daun dan sudut daun pada tajuk tanaman sangat menentukan serapan sinar matahari. Tiap helai daun serapan

Tabel 5. Rata-rata nilai klorofil 30 hst dan 70 hst jarak tanam 70 × $20 \mathrm{~cm}$ (populasi 71.428 $\tan . /$ ha) dan $70 \times 15 \mathrm{~cm}$ (populasi $95.238 \mathrm{tan} . / \mathrm{ha}$ ).

\begin{tabular}{|l|l|l|l|l|}
\hline \multirow{3}{*}{ Varietas } & \multicolumn{3}{|c|}{ Nilai klorofil daun $30 \mathrm{hst}$} & \multicolumn{1}{c|}{ Nilai klorofil daun 70 hst } \\
\cline { 2 - 5 } & \multicolumn{4}{|c|}{ Populasi tanaman per hektar } \\
\cline { 2 - 5 } & \multicolumn{1}{|c|}{71.428} & \multicolumn{1}{|c|}{95.238} & 71.428 & 95.238 \\
\hline Pionner 21 & $49.76 \mathrm{a}$ & $45.40 \mathrm{ab}$ & $57.27 \mathrm{ab}$ & $52.50 \mathrm{a}$ \\
\hline Fasific 224 & $48.88 \mathrm{ab}$ & $41.90 \mathrm{abc}$ & $58.26 \mathrm{a}$ & $49.57 \mathrm{a}$ \\
\hline Bisi 2 & $43.66 \mathrm{~d}$ & $39.83 \mathrm{c}$ & $48.74 \mathrm{c}$ & $48.32 \mathrm{a}$ \\
\hline Bima 3 & $46.34 \mathrm{a}-\mathrm{d}$ & $45.89 \mathrm{a}$ & $53.74 \mathrm{abc}$ & $52.18 \mathrm{a}$ \\
\hline Bima 4 & $45.03 \mathrm{~cd}$ & $43.34 \mathrm{abc}$ & $53.10 \mathrm{abc}$ & $54.31 \mathrm{a}$ \\
\hline Bima 5 & $48.69 \mathrm{abc}$ & $46.76 \mathrm{a}$ & $55.47 \mathrm{ab}$ & $54.40 \mathrm{a}$ \\
\hline Bima 19 & $45.24 \mathrm{bcd}$ & $44.11 \mathrm{abc}$ & $51.69 \mathrm{bc}$ & $52.54 \mathrm{a}$ \\
\hline Bima 20 & $45.73 \mathrm{bcd}$ & $40.38 \mathrm{bc}$ & $49.21 \mathrm{c}$ & $47.63 \mathrm{a}$ \\
\hline Rata-rata & 46.67 & 43.45 & 53.43 & 51.43 \\
\hline
\end{tabular}

Angka yang diikuti huruf yang sama tidak berbeda nyata pada taraf 5\% menurut uji Duncan sinar matahari berbeda tergantung pada sebaran daun dalam tajuk, posisi daun semakin dekat dengan permukaan tanah semakin berkurang jumlah sinar matahari yang diterima oleh daun akibat diserap daun bagian atas (ternaungi) (Ramli, 2019); (Stewart, et. al., 2003).

Nilai klorofil daun pada 70 hst dengan populasi 71.428 tan./ha menunjukkan bahwa varietas Fasific 224 berbeda nyata dengan Bisi 2 dan Bima 20, namun tidak berbeda nyata dengan Pionner 21, Bima 3, Bima 4 dan Bima 5, sedang pada 70 hst seluruh varietas nilai klorofil daun tidak berbeda nyata (Tabel 5). Pada populasi rendah masing-masing varietas masih memberikan kemampuan yang berbeda terhadap nilai klorofil daun yang dipengaruhi oleh tingkat kompetisi antar tanaman yang rendah, namun pada populasi lebih tinggi tingkat kompetisi antar tanaman meningkat sehingga kemampuan nilai klorofil hampir sama. Populasi tanaman sangat berpengaruh terhadap kondisi iklim mikro, kompetisi (intensitas serapan cahaya matahari) dan kelembaban, sedang tingkat populasi yang optimum dan dapat memanfaatkan cahaya matahari yang optimal berdampak yang positif pada produktivitas tanaman (Wahyudin dan Surahman, 2018). 


\section{Produksi (t/ha)}

Hasil analisis menunjukkan bahwa pada populasi 71.428 tan./ha produksi varietas Fasific 224 berbeda nyata dengan seluruh varietas kecuali Pionner 21, sedang pada populasi 95.238 tan./ha varietas Bisi 2 dan Bima 4 berbeda nyata dengan Pionner 21 dan Bima 20, namun tidak berbeda nyata Fasific 224, Bima 3, Bima 5, dan Bima 19 (Tabel 6). Hal ini menunjukkan bahwa masing-masing varietas memberikan produksi yang berbeda sesuai kemampuan tanaman terhadap lingkungan (populasi) dan jenis varietasnya. Pertumbuhan dan produktivitas jagung sangat dipengaruhi oleh jarak tanaman (tingkat populasi) dan jenis varietas (Yulisma, 2011).

Varietas Pionner 21 dan Fasific 224 dengan peningkatan populasi terjadi penurunan produksi, namun varietas lain terjadi peningkatan produksi. Peningkatan populasi pada varietas Pionner 21 dan Fasific 224 terjadi kompetisi unsur hara, air cahaya matahari dan ruang tumbuh yang lebih besar dibanding varietas lain ditandai dengan penurunan produksi. Jarak tanam yang semakin rapat maka tingkat kompetisi

tanaman semakin besar, sehingga jumlah polong isi tiap tanaman kedelai semakin menurun seiring penyempitan jarak tanam (Aisah dan Herlina, 2018).

Varietas Bisi 2, Bima 3, Bima 4, bima 5, Bima 19 dan Bima 20 dengan peningkatan populasi terjadi kenaikkan produksi tergantung dari jenis varietas. Peningkatan produksi menujukkan bahwa varietas tersebut mampu memanfaatkan unsur hara, cahaya matahari, air dan ruang tumbuh yang optimal pada populasi 71.428 ta/ha ke populasi 95.238 tan/ha. Tanaman yang mampu beradaptasi akibat perubahan tingkat populasi terhadap perubahan iridiasi dengan memodifikasi morfologi dan fisiologi, energi cahaya matahari yang tersedia dapat digunakan secara efisien (Koike, 2013). Namun menurut Aisah dan Herlina (2018) melaporkan bahwa semakin rapat jarak tanam maka cahaya matahari yang diterima oleh tanaman semakin berkurang yang mengakibatkan proses fotosintesis terhambat sehingga produksi menurun.

Tabel 6. Rata-rata hasil jarak tanam $70 \mathrm{x}$ $20 \mathrm{~cm}$ (populasi $71.428 \mathrm{tan} . / \mathrm{ha}$ ) dan $70 \mathrm{x}$ $15 \mathrm{~cm}$ (populasi $95.238 \mathrm{tan} . / \mathrm{ha}$ ).

\begin{tabular}{|l|l|l|}
\hline \multirow{3}{*}{ Varietas } & \multicolumn{2}{|c|}{ Produksi (t/ha) } \\
\cline { 2 - 3 } & \multicolumn{2}{|c|}{$\begin{array}{c}\text { Populasi tanaman per } \\
\text { hektar }\end{array}$} \\
\cline { 2 - 3 } & \multicolumn{1}{|c|}{71.428} & \multicolumn{1}{c|}{95.238} \\
\hline Pionner 21 & $7.31 \mathrm{ab}$ & $5.66 \mathrm{~b}$ \\
\hline Fasific 224 & $8.56 \mathrm{a}$ & $7.65 \mathrm{ab}$ \\
\hline Bisi 2 & $6.60 \mathrm{bc}$ & $8.85 \mathrm{a}$ \\
\hline Bima 3 & $7.05 \mathrm{~b}$ & $7.53 \mathrm{ab}$ \\
\hline Bima 4 & $6.35 \mathrm{bc}$ & $8.50 \mathrm{a}$ \\
\hline Bima 5 & $6.82 \mathrm{~b}$ & $7.49 \mathrm{ab}$ \\
\hline Bima 19 & $5.88 \mathrm{bc}$ & $7.94 \mathrm{ab}$ \\
\hline Bima 20 & $5.27 \mathrm{c}$ & $5.86 \mathrm{~b}$ \\
\hline Rata-rata & 6.73 & 7.43 \\
\hline
\end{tabular}

Angka yang diikuti huruf yang sama tidak berbeda nyata pada taraf 5\% menurut uji Duncan

\section{Bobot 100 Biji}

Hasil analisis menunjukkan bahwa bobot 100 biji tidak berbeda nyata dari seluruh varietas pada populasi 71.428 tan./ha dan 95.238 tan./ha (Tabel 7). Hal ini menujukkan varietas dan populasi tidak berpengaruh terhadap bobot 100 biji. Namun peningkatan populasi dari $71.428 \mathrm{tan} . /$ ha ke 95.238 tan./ha terjadi penurunan nilai bobot 100 biji kecuali varietas Pionner dan Bisi 2. Pengurangan bobot 100 biji dengan peningkatan populasi dikarenakan berkurangnya alokasi fotosintat ke biji akibat berkurangya intensitas cahaya menyebabkan fotosintesis terganggu. 
Berkurangnya cahaya matahari dapat mengakibatkan proses fotosintesis berkurang, sehingga alokasi fotosintat dalam pembentukan organ vegetatif maupun reproduktif berkurang (Sundari dan Mutmaidah, 2018).

Tabel 7. Rata-rata bobot 100 biji jarak tanam $70 \times 20 \mathrm{~cm}$ (populasi 71.428 $\tan . /$ ha) dan $70 \times 15 \mathrm{~cm}$ (populasi 95.238 $\tan . /$ ha).

\begin{tabular}{|c|c|c|}
\hline \multirow{3}{*}{ Varietas } & \multicolumn{2}{|c|}{ Bobot 100 biji (g) } \\
\hline & \multicolumn{2}{|c|}{$\begin{array}{l}\text { Populasi tanaman per } \\
\text { hektar }\end{array}$} \\
\hline & 71.428 & 95.238 \\
\hline Pionner 21 & $31.74 a$ & $33.71 \mathrm{a}$ \\
\hline Fasific 224 & $38.49 \mathrm{a}$ & $33.65 \mathrm{a}$ \\
\hline Bisi 2 & $30.60 \mathrm{a}$ & $34.42 \mathrm{a}$ \\
\hline Bima 3 & $33.97 \mathrm{a}$ & $31.70 \mathrm{a}$ \\
\hline Bima 4 & $35.27 \mathrm{a}$ & $33.36 \mathrm{a}$ \\
\hline Bima 5 & $33.30 \mathrm{a}$ & $28.90 \mathrm{a}$ \\
\hline Bima 19 & $31.52 \mathrm{a}$ & $30.35 a$ \\
\hline Bima 20 & $32.76 \mathrm{a}$ & $32.38 \mathrm{a}$ \\
\hline Rata-rata & 33.46 & 32.31 \\
\hline
\end{tabular}

Angka yang diikuti huruf yang sama tidak berbeda nyata pada taraf $5 \%$ menurut uji Duncan

\section{Panjang Tongkol}

Panjang tongkol pada populasi 71.428 tan./ha menunjukkan bahwa varietas Fasific 224 berbeda nyata seluruh varietas kecuali Bima 4, sedang populasi 95.238 tan./ha Bima 5 berbeda nyata Pionner 21 dan Bima 19, namun tidak berbeda nyata varietas lainnya (Tabel 8). Varietas Pionner 21, Fasific 224, Bima 3, Bima 4, Bima 19 dan Bima 20 dengan peningkatan populasi terjadi penurunan nilai panjang tongkol. Hal ini menunjukkan bahwa dengan meningkatnya populasi tingkat kompetisi cahaya matahari, air, unsur hara dan ruang tumbuh mempengaruhi panjang tongkol pada varietas tersebut. Sedang peningkatan populasi pada varietas Bisi 2 dan Bima 5 terjadi peningkatan nilai panjang tongkol. Dengan meningkatnya nilai panjang tongkol seiring bertambahnya tingkat populasi mengindikasikan varietas tersebut mampu mengoptimal kompetisi unsur hara, cahaya matahari, air dan ruang tumbuh. Tanaman yang memiliki kemampuan beradaptasi terhadap perubahan iridiasi dengan memodifikasi morfologi dan fisiologi, energi cahaya matahari yang tersedia dapat dimanfaatkan secara efisien (Koike, 2013), sehingga dengan peningkatan populasi masih mampu meningkatkan nila panjang tongkol.

Diameter tongkol pada populasi 71.428 tan./ha menunjukkan bahwa varietas Fasific 224, Bima 3, Bima 4 dan Bima 5 berbeda nyata dengan Bisi 2 dan Bima 20, sedangkan populasi 95.238 tan./ha varietas Pionner 21 berbeda nyata Fasific 224, Bisi 2 dan Bima 20, namun tidak berbeda nyata dengan Bima 3, Bima 4 dan Bima 5. Varietas Pionner 21 dari populasi 71.428 tan./ha ke populasi 95.238 tan./ha terjadi peningkatan nilai diameter tongkol, sedang varietas lain terjadi penurunan. Dengan peningkatan populasi terjadi peningkatan diameter tongkol varietas Pionner 21 menujukkan bahwa meskipun terjadi kompetisi cahaya matahari, air, unsur hara dan ruang tumbuh varietas Pionner 21 mampu mengoptimalkan kompetisi tersebut. Tanaman yang memiliki adaptasi terhadap perubahan iridiasi yaitu dengan memodifikasi morfologi, fisiologi, menyerap cahaya matahari yang tersedia dapat digunakan secara efisien (Koike, 2013). Sedang varietas lain terjadi penurunan diameter tongkol seiring meningkatnya populasi. Dengan peningkatan populasi varietas Fasific 224 tidak terjadi peningkatan diameter tongkol yang siknifikan, hal ini mengindikasikan varietas Fasific 224 tidak mampu mengoptimalkan cahaya matahari, air, hara dan ruang tumbuh. 
Aisah dan Herlina (2018) melaporkan bahwa jarak tanam yang semakin rapat cahaya matahari yang diterima oleh tanaman semakin berkurang berakibat proses fotosintesis terhambat sehingga produksi menurun.

Tabel 8. Rata-rata panjang dan diameter tongkol jarak tanam $70 \times 20 \mathrm{~cm}$ (populasi 71.428 $\tan . /$ ha) dan 70 x $15 \mathrm{~cm}$ (populasi 95.238 tan./ha).

\begin{tabular}{|c|c|c|c|c|}
\hline \multirow{3}{*}{ Varietas } & \multicolumn{2}{|c|}{ Panjang tongkol $(\mathrm{cm})$} & \multicolumn{2}{|c|}{ Diameter tongkol $(\mathrm{cm})$} \\
\hline & \multicolumn{4}{|c|}{ Populasi tanaman per hektar } \\
\hline & 71.428 & 95.238 & 71.428 & 95.238 \\
\hline Pionner 21 & $15.42 b$ & $14.36 \mathrm{c}$ & $4.01 \mathrm{ab}$ & $4.74 \mathrm{a}$ \\
\hline Fasific 224 & $17.92 \mathrm{a}$ & $16.06 \mathrm{ab}$ & $4.25 \mathrm{a}$ & $4.37 b$ \\
\hline Bisi 2 & $15.21 \mathrm{~b}$ & $15.75 \mathrm{ab}$ & $3.74 \mathrm{c}$ & $4.31 b$ \\
\hline Bima 3 & $15.73 \mathrm{~b}$ & $15.36 \mathrm{abc}$ & $4.17 \mathrm{a}$ & $4.58 \mathrm{ab}$ \\
\hline Bima 4 & $16.95 \mathrm{ab}$ & $15.33 \mathrm{abc}$ & $4.18 \mathrm{a}$ & $4.59 \mathrm{ab}$ \\
\hline Bima 5 & $15.23 b$ & $16.28 \mathrm{a}$ & $4.25 \mathrm{a}$ & $4.56 \mathrm{ab}$ \\
\hline Bima 19 & $15.11 \mathrm{~b}$ & $14.08 \mathrm{c}$ & $4.04 \mathrm{ab}$ & $4.60 \mathrm{ab}$ \\
\hline Bima 20 & $15.93 b$ & $14.90 \mathrm{bc}$ & $3.89 \mathrm{bc}$ & $4.36 b$ \\
\hline Rata-rata & 15.94 & 15.26 & 4.07 & 4.51 \\
\hline
\end{tabular}

Angka yang diikuti huruf yang sama tidak berbeda nyata pada taraf 5\% menurut uji Duncan

\section{Jumlah Baris dan Biji dalam Baris}

Hasil analisis menujukkan bahwa pada populasi 71.428 tan./ha jumlah baris varietas Pionner 21 tidak berbeda nyata dengan Fasific 224, namun berbeda nyata varietas lain, sedangkan populasi 95.238 tan./ha varietas Pionner 21 dan Bima 3 berbeda nyata Bima 4 dan Bima 20. Pada populasi 71.428 tan./ha jumlah biji dalam baris varietas Fasific 224 berbeda nyata dengan Pionner 21, Bima 19 dan Bima 20, sedangkan populasi 95.238 tan./ha varietas Bisi 2 tidak berbeda nyata dengan varietas Fasific 224, namun berbeda nyata dengan varietas lain (Tabel 9). Dengan peningkatan populasi 71.428 $\tan . /$ ha ke 95.238 tan./ha jumlah baris dan jumlah biji dalam baris tidak terjadi kenaikkan ataupun penurunan yang siknifikan. Seluruh varietas pada kedua parameter tersebut tidak berpengaruh nilai jumlah baris dan jumlah biji dalam baris yang siknifikan terhadap kedua populasi. Hal ini menunjukkan varietas mampu mengoptimalkan dalam pembentukkan jumlah baris dan jumlah biji dalam baris. Jumlah baris sangat dipengaruhi oleh diameter tongkol, sedang jumlah biji dalam baris dipengaruhi oleh saat fase penyerbukan dan pengisian biji yaitu bila terjadi cekaman kekeringan penyerbukan dan pengisian biji tidak sempurna yang berakibat jumlah biji tidak maksimal (Suwardi, 2016). 
Tabel 9. Rata-rata jumlah baris dan jumlah biji dalam baris jarak tanam 70 x $20 \mathrm{~cm}$ (populasi $71.428 \tan . /$ ha) dan $70 \times 15 \mathrm{~cm}$ (populasi $95.238 \mathrm{tan} . / \mathrm{ha}$ ).

\begin{tabular}{|c|c|c|c|c|}
\hline \multirow{3}{*}{ Varietas } & \multicolumn{2}{|c|}{ Jumlah baris } & \multicolumn{2}{|c|}{ Jumlah biji dalam baris } \\
\hline & \multicolumn{4}{|c|}{ Populasi tanaman per hektar } \\
\hline & 71.428 & 95.238 & 71.428 & 95.238 \\
\hline Pionner 21 & $14.22 \mathrm{a}$ & $14.33 \mathrm{a}$ & $31.83 \mathrm{c}$ & 31.66de \\
\hline Fasific 224 & $13.67 \mathrm{ab}$ & $13.00 \mathrm{a}-\mathrm{d}$ & $37.44 a$ & $38.05 \mathrm{ab}$ \\
\hline Bisi 2 & $12.55 \mathrm{e}$ & $12.78 \mathrm{bcd}$ & $33.94 b c$ & $39.55 a$ \\
\hline Bima 3 & $13.55 \mathrm{~b}$ & $14.33 \mathrm{a}$ & $33.28 \mathrm{bc}$ & $33.77 \mathrm{~cd}$ \\
\hline Bima 4 & 12.66de & $12.44 \mathrm{~cd}$ & $33.55 \mathrm{bc}$ & $34.11 \mathrm{bcd}$ \\
\hline Bima 5 & $13.33 \mathrm{bc}$ & 13.22abc & $35.78 \mathrm{ab}$ & $36.39 \mathrm{abc}$ \\
\hline Bima 19 & $13.22 \mathrm{bcd}$ & $14.11 \mathrm{ab}$ & $32.11 \mathrm{c}$ & $33.89 \mathrm{~cd}$ \\
\hline Bima 20 & $12.88 \mathrm{cde}$ & $11.78 \mathrm{~d}$ & $31.89 \mathrm{c}$ & $29.72 \mathrm{e}$ \\
\hline Rata-rata & 13.26 & 13.25 & 33.73 & 34.64 \\
\hline
\end{tabular}

Angka yang diikuti huruf yang sama tidak berbeda nyata pada taraf 5\% menurut uji Duncan

\section{KESIMPULAN}

Varietas dan populasi tanaman tidak memberikan pengaruh yang siknifikan terhadap fase generatif dan vegetatif tanaman, namun berpengaruh terhadap hasil (t/ha). Produksi tertinggi populasi $71.428 \tan /$ ha Fasific $224(8,56$ t/ha) dan 95.238 tan/ha Bisi 2 (8,85 t/ha). Untuk meningkatkan produktivitas melalui tingkat populasi $71.428 \mathrm{tan} / \mathrm{ha}$ menjadi 95.238 tan/ha dengan menggunakan varietas Bisi $2 \quad(6,60$ menjadi 8,85 ton/ha) kenaikkan 25,51\%, Bima 4 (6,35 menjadi 8,50 ton/ha) kenaikkan 25,38\% dan Bima 19 (5,88 menjadi 7,94 ton/ha) kenaikkan 25,94\%. Peningkatan produksi dengan populasi tanaman adalah varietas Bisi 2, Bima 4, dan Bima 19. Varietas tersebut direkomendasikan untuk pengguna/petani dalam meningkatkan produktivitas.

\section{DAFTAR PUSTAKA}

Aisah Y. dan H N. 2018. Pengaruh Jarak Tanam Jagung Manis (Zea mays L. Var. Saccharata) pada Tumpangsari dengan Tiga Varietas Tanaman Kedelai (glysin $\max$ (L) Merrill).
Jurnal Produksi Tanaman, 6(1):6675.

Alislami T. C. K., Suryanto S. 2018. Pengaruh Sistem Tanam dan Mulsa Terhadap Effisiensi Konversi Radiasi Matahari pada Tanaman Jagung (Zea mays var. Identata) Varietas Pertiwi 3. Jurnal Produksi Tanaman, 8(1):158-165.

Borra's, L., G.A. Maddonni, and M.E. Otegui. 2003. Leaf senescence in maize hybrids: Plant population, row spacing and kernel set effects. Field Crops Res. 82:13-26.

Campillo C., R. Fortes and M. H. Prieto. 2012. Solar Radiation Effect on Crop Production. Elisha B. Babatunde, (ed). University Campus Step Ri Slavka Krautzeka. Croatia. Pp. 167-194.

Erawati B. dan Hippi A. 2015. Pengaruh Jarak Tanam terhadap Pertumbuhan dan Hasil Beberapa Varietas Jagung Hibrida di Kawasan Pengembangan Jagung Kabupaten Sumbawa. Prosiding Seminar Nasional Inovasi Teknologi Pertanian, Banjarbaru, 20 Juli 2016.

Firdaus, K. Arifuddin, H. G. Yasin. 2002. Metode Pendugaan Hasil Jagung. 
Pusat Penelitian dan Pengembangan Tanaman Pangan. Balitsereal, Maros. INA.

Franklin, K. A. 2008. Shade Avoidance. New Phytol, 170:930-944.

Gardner, F. P. Pearce. R. B. And Michel R. L. 1996. Physiology of crop plant. Terjemahan Herawati, Susilo dan Subiyanto. UI Pres, Jakarta, 343: 61-68.

Haque, M. M., M. Hasanuzzaman, M. L. Rahman. 2009. Effect of Ligth Intensity on The Morphophisiology and Yield of Bottle Grourd (Lagenaria vulagaris) Acad. J. Plant Sci, 2:158-161.

Koike, Y. 2013. Effect of Iridiance Level on The Growth and Photosynthesis of Salvia. Int. J. Evriron. Sci. Dev, $4: 478-482$.

https://citeseerx.ist.psu.edu/viewdo $\underline{\mathrm{c}}$

/download?doi=10.1.1.678.2639\&r $\mathrm{ep}=\mathrm{rep} 1 \&$ type $=\mathrm{pdf}$.

Li, C. Y., S. Z. Dong, C. H. Zhu. And Y. S. Zhen, 2006. Influence of Shanding Stress During Different Growth Stage on Yield and Main Characters of Soybean. Southwest China. J. Agric. Sei, 19:265-269.

Nurbaiti, F. G. Haryono dan A. Suprapto 2017. Pengaruh Pemberian Mulsa dan Jarak Tanam pada Hasil Kedelai (Glycine max. L. Merril) Varietas Grobogan. Vigor: Jurnal Ilmu Pertanian Tropika dan Subtropika, 2(2): 41-47.

Ramli L. 2019. Pengaruh Pemangkasan Daun Disekitar Tongkol Terhadap Pengisian Biji Tanaman Jagung (Zea mays L.). Agrium, 22(1):7075.

Stewart, D.W., C. Costa, L.M. Dwyer, D.L. Smith, R.I. Hamilton, and B.L. Ma. 2003. Canopy Structure, Light Interception, and Photosynthesis in Maize. Agron. J., 95:1465-1474.
Sundari T. dan Mutmaidah S., 2018. Kesesuaian Galur-galur Harapan Kedelai untuk Tumpangsari Jagung + Kedelai. Jurnal Agronomi Indonesia, 46(1): 40-47.

Suwardi. 2016. Keragaman Hasil dan Toleransi Kekeringan Genotipe Jagung Terhadap Ketersediaan Air. Hal. 401-410. Prosiding Seminar Peranan Biologi dalam Peningkatan Konservasi Keragaman Hayati. Fakultas Matematika dan Ilmu Pengetahuan Alam. Universitas Hasanuddin, Makassar 6 Jumi 2016.

Suwardi dan Fauziah Koes. 2016. Pengaruh Waktu Pemotongan Batang Di Atas Tongkol Terhadap Hasil Komponen Hasil dan Biomas pada Berbagai Varietas Jagung Hibrida. Hal.51-58. Prosiding Seminar Nasional. Membangun Pertanian Moedrn dan Inovatif Berkelanjutan dalam Rangka Mendukung MEA. BPTP Jambi 31 Mei-1 Juni 2006.

Kartikan T. 2018. Pengaruh Jarak Tanam Terhadap Pertumbuhan dan Produksi Jagung (Zea mays L.) non Hibrida di Lahan Balai Agro Teknologi Tepadu. Jurnal Ilmiah Matematika dan Ilmu Pengetahuan Alam. Sainmatika, 15(2):129-139. https://jurnal.univpgripalembang.ac.id/index.php/sainmat ika/article/view/2378.

Wahyudi M. I dan Surahman M. A. 2018. Uji Jarak Tanam dan Implikasinya Terhadap Produktivitas dan Intensitas Serangan Penyakit pada Beberapa Varietas Jagung Hibrida (Zea mays L.) di Kabupaten Jember. Jurnal Agritrop, 16(1): 6180.

https://www.neliti.com/publications $\underline{1273700}$

Yulisma 2011. Pertumbuhan dan Hasil Beberapa Varietas Jagung pada Berbagai Jarak Tanam. Jurnal 


\section{Penelitian Pertanian Tanaman} Pangan, 30(3):196-203.

Zhang, J., D. L. Smith, W. G. Liu, F. X. Chen, and W. Y. Yang. 2011. Effect of Shade and Drought Stress on Soybean Homones and Yield of Main-stem and Branch. Afr. Journal Biotechnol, 10:14392-14398.

https://academicjournals.org/journal/AJB/ article-full-text-pdf/60E0A 5734016 